Magdalena ŚNIEDZIEWSKa

Uniwersytet Wrocławski

\title{
Rembrandt i samotność Chrystusa: \\ *** [Tak jak męczennik światłocienia - Rembrandt...] Osipa Mandelsztama i Ewangelia także jako arcydzieło literatury Aleksandra Wata
}

Schyłek XVII wieku zaowocował - jak podkreśla Anne Chalard-Fillaudeau pierwszymi utworami literackimi oraz rozprawami filozoficznymi, których głównym bohaterem stał się zmarly na początku tego stulecia Rembrandt. Celem tych utworów nie była wyłącznie rekonstrukcja biografii wielkiego malarza czy też refleksja nad technicznym aspektem jego twórczości; chodziło w nich raczej o uczynienie $\mathrm{z}$ historycznej postaci swego rodzaju mitu, w którym przeglądać mogliby się autorzy kolejnych stuleci. Z tego powodu postać Rembrandta podlegała licznym próbom mitologizacji (zob. Chalard-Fillaudeau 2004: 13-27; McQueen 2003: 47-53; Rosales Rodríguez 2008: 37-53, 181-197; Śniedziewska 2014: 228-277), zaś sposoby jej funkcjonowania w konkretnych utworach można opisać, odwołując się do różnych modalności - od przywołania na prawach cytatu, poprzez aluzję, do transpozycji włącznie (zob. Chalard-Fillaudeau 2004: 293). W tak nakreślonym imaginarium szczególną rolę odgrywają, jak sądzę, nieopisane dotychczas przez badaczy relacje między tekstami a nie samym Rembrandtem, ale postaciami pojawiającymi się na jego płótnach. Interesującym mnie przypadkiem takiej relacji jest związek, jaki istnieje pomiędzy wierszem ${ }^{* * *}$ [Tak jak męczennik światłocienia - Rembrandt...] Osipa Mandelsztama, szkicem Ewangelia także jako arcydzieło literatury Aleksandra Wata a Rembrandtowskim wyobrażeniem Chrystusa oraz - co istotne w przypadku Wata - batawskiego wodza, Claudiusa Civilisa. 
Larry Silver i Shelley Perlove w szkicu Rembrandt's Jesus dowodzą, że „Rembrandt w specyficzny sposób traktuje narrację religijną, często łączy różne biblijne epizody w jednym obrazie, czasem zaś destyluje świętą postać do portretopodobnego przedstawienia" (Silver, Perlove 2011: 75). W swoim artykule chciałabym zastanowić się nad tym, jaki portret Chrystusa ujrzeli w „historiach” Rembrandta Mandelsztam i Wat.

\section{Golgota Osipa Mandelsztama}

Wspomnienia Nadieżdy Mandelsztam potraktować można nie tylko jako kronikę epoki, w której opisane zostały nieprawdopodobne okrucieństwa czasów stalinowskich, ale także jako poruszającą biografię jej męża, wielkiego rosyjskiego poety, Osipa Mandelsztama, ofiary sowieckiego reżimu. Snuta przez nią opowieść poraża autentycznością, a Osip Mandelsztam jawi się jako jeden z licznych męczenników, którym przyszło żyć w czasach „więziennej «cywilizacji»" (Mandelsztam 2015: 40). Więzienie, o którym Nadieżda Mandelsztam pisze - wypowiadając się w imieniu Rosjan - że „mocno tkwiło w naszej świadomości” (Mandelsztam 2015: 154), w stalinowskiej rzeczywistości zmieniło się w przerażająco dosłowną metaforę.

Męczeństwo Mandelsztama nie było jednak - jak zaznacza jego żona - świadomą pozą poety, ale konsekwencją nieludzkich praktyk, znamionujących rządy Stalina. Nadieżda Mandelsztam wyraźnie daje do zrozumienia, że w przypadku jej męża silne pragnienie życia przegrało z jeszcze silniejszym terrorem: „Do pogodzenia się z rzeczywistością skłaniać też mogło najzwyczajniejsze umiłowanie życia. O.M. nie miał żadnego pociągu do męczeństwa, ale za prawo do życia trzeba było płacić zbyt dużą cenę" (Mandelsztam 2015: 158). Autorka Wspomnień podkreśla, że wielu Rosjan podzieliło los jej męża. Na „sowieckiej Golgocie” do kresu doprowadzono całą rzeszę męczenników: „Los nie jest tajemniczą siłą płynącą z zewnątrz, ale wypadkową wewnętrznego ładunku człowieka i głównej tendencji epoki; co prawda w naszych czasach niemało męczeńskich życiorysów skrojono według jednego potwornego szablonu” (Mandelsztam 2015: 148). Wiemy, że długa jest lista męczenników czasów stalinowskich. Wyjątkowość Osipa Mandelsztama, fakt, że to właśnie jego imię i nazwisko przetrwało jako jedna z niezabliźnionych ran strasznej historii dwudziestowiecznych totalitaryzmów, nie tkwi zatem w męczeńskim życiorysie, ale w sile jego poetyckiego słowa.

W kontekście wspominanych przez Nadieżdę Mandelsztam historii męczenników na myśl nasuwają się skojarzenia z męką Chrystusa. Te aluzje nie

1 Tłumaczenia wszystkich cytatów, jeśli nie zaznaczono inaczej, pochodzą od autorki artykułu. 
są ani przypadkowe, ani przesadzone. I nawet jeśli „męczeńskie życiorysy” nie należały do wyjątków, to każdy z ich właścicieli, oczekując śmierci, doświadczał podobnego osamotnienia co modlący się w Ogrójcu Chrystus. Nadieżda Mandelsztam stawia ważną tezę, że w przypadku ludzi skazanych przez sowieckie władze świadomość nadchodzącej śmierci była o wiele gorsza niż samo wykonanie wyroku:

Zrozumieć w pełni modlitwę o oddalenie kielicha może tylko ktoś, kto wie, jak trudne do zniesienia jest powolne, systematyczne zbliżanie się do śmierci. O wiele trudniej jest czekać na „ołowiu ziarnko”, niż upaść na ziemię po strzale. Czekaliśmy na koniec przez cały ostatni rok w Woroneżu, a potem jeszcze przez rok tułaczki pod Moskwą (Mandelsztam 2015: 254).

W tym fragmencie wspomnień Nadieżda Mandelsztam pomieściła dwa literackie odniesienia - pierwsze to aluzja biblijna, która każe myśleć o fragmencie Ewangelii opisującym modlitwę Chrystusa w Getsemani. Autorka podkreśla, że okoliczności, w jakich na zesłaniu oczekiwała wraz z mężem śmierci, pozwalają w pełni pojąć sens słów Chrystusa, który - jako człowiek lękający się tego, co ma nadejść - prosi Boga, by ominął go ten kielich. Jakby ciężar boskiego planu odkupienia był zbyt duży, by mogły udźwignąć go ludzkie barki Chrystusa. Wydłużające się oczekiwanie, rosnąca i przytłaczająca świadomość nadchodzącego kresu, którego nie da się uniknąć, sprawiają, że kurczowe trzymanie się życia staje się trudniejsze niż doświadczenie bólu związanego ze śmiercią. Spójrzmy na wywołany przez Nadieżdę Mandelsztam fragment Ewangelii według św. Mateusza (Mt 26,36-46):

Wtedy przyszedł Jezus z nimi do ogrodu, zwanego Getsemani, i rzekł do uczniów: „Usiądźcie tu, Ja tymczasem odejdę tam i będę się modlił”. Wziąwszy z sobą Piotra i dwóch synów Zebedeusza, począł się smucić i odczuwać trwogę. Wtedy rzekł do nich: „Smutna jest moja dusza aż do śmierci; zostańcie tu i czuwajcie ze Mną!”. I odszedłszy nieco dalej, upadł na twarz i modlił się tymi słowami: „Ojcze mój, jeśli to możliwe, niech Mnie ominie ten kielich! Wszakże nie jak Ja chcę, ale jak Ty”. Potem przyszedł do uczniów i zastał ich śpiących. Rzekł więc do Piotra: „Tak, jednej godziny nie mogliście czuwać ze Mną? Czuwajcie i módlcie się, abyście nie ulegli pokusie; duch wprawdzie ochoczy, ale ciało słabe”. Powtórnie odszedł i tak się modlił: „Ojcze mój, jeśli nie może ominąć Mnie ten kielich, i muszę go wypić, niech się stanie 
wola Twoja!”. Potem przyszedł i znów zastał ich śpiących, bo oczy ich były senne. Zostawiwszy ich, odszedł znowu i modlił się po raz trzeci, powtarzając te same słowa. Potem wrócił do uczniów i rzekł do nich: „Śpicie jeszcze i odpoczywacie? A oto nadeszła godzina i Syn Człowieczy będzie wydany w ręce grzeszników. Wstańcie, chodźmy! Oto blisko jest mój zdrajca" (Pismo Święte 1990: 1154).

Drugie nawiązanie to cytat z wiersza Anny Achmatowej, napisanego w latach trzydziestych $\mathrm{xx}$ wieku:

Jeśli mierzyć zwykłą miarką,

Za takie figle, bądźmy szczerzy,

Jedno mi ołowiu ziarnko

Od sekretarza się należy

(Achmatowa 2007: 68).

Pozornie lekki ton tej poetyckiej miniatury skrywa przerażającą tezę o powszedniości śmierci w Rosji czasów stalinowskich. „Ołowiu ziarnko” rozsiewane było hojnie i z niewiarygodną łatwością, gdyż wszelkie etyczne zasady uległy zawieszeniu.

Twórczości Osipa Mandelsztama nie można w pełni zrozumieć, jeśli nie pozna się zawikłanych ścieżek jego losu, które pod koniec życia zamieniają się w drogę krzyżową. We Wspomnieniach autorstwa jego żony odnajdujemy fragment przekonujący nas o konieczności biograficznej lektury tej poezji: „O.M. tak mocno otwierał się w wierszach, że zostawało w nim, przynajmniej dla mnie, bardzo mało ciemnych miejsc" (Mandelsztam 2015: 87). To przekonanie nieobce jest także badaczom twórczości rosyjskiego poety. Clarence Brown podkreśla, że w przypadku Mandelsztama „poezji nie można zrozumieć bez znajomości jego życia” (Brown 1967: 586). Jednak nie tylko biografia rosyjskiego poety, rekonstruowana na podstawie pamiętnikarskiej narracji jego żony, stanowi istotny kontekst pozwalający zrozumieć tę twórczość. Także poglądy estetyczne, wyrażone w szkicach pisanych u progu xx stulecia, stają się istotnym tłem dla jego utworów poetyckich.

W kontekście rozważań na temat śmierci warto przywołać fragmenty szkicu Mandelsztama Skriabin i chrześcijaństwo z 1915 roku:

Puszkin i Skriabin to dwa przeistoczenia jednego słońca, dwa przeistoczenia jednego serca. Dwakroć śmierć artysty zgromadziła naród rosyjski i zapaliła nad nim swoje słońce. Obaj dali przykład publicz- 
nego, rosyjskiego zgonu, zmarli pełnia śmierci, tak jak się żyje pełnią życia, ich indywidualność umierając, rozrosła się w symbol całego narodu, a słońce-serce umierającego zatrzymało się na wieki w zenicie cierpienia i sławy.

Chcę rzec o śmierci Skriabina jako najwyższym akcie jego twórczości. Śmierci artysty nie należy, jak sądzę, wyłączać z łańcucha jego dokonań twórczych, lecz uznać ją trzeba za ostatnie, zamykające ogniwo (Mandelsztam 2011: 60).

Komentując fragment poświęcony śmierci Skriabina, Agata Stankowska stwierdza: „Moglibyśmy powiedzieć, że tymi słowy Mandelsztam otwierał proroczo perspektywę na własną, nieprzeczuwaną przecież jeszcze wówczas śmierć" (Stankowska 2013: 257). W eseju Skriabin i chrześcijaństwo Mandelsztam dokonuje istotnego uogólnienia rozważań o śmierci:

Artyści chrześcijańscy są jak wyzwoleńcy idei odkupienia, a nie jej słudzy ani głosiciele. Cała nasza dwutysiącletnia kultura dzięki cudownej łasce chrześcijaństwa to akt, który daje światu wolność - wolność zabawy, duchowego rozradowania, swobodnego „naśladowania Chrystusa”.

Chrześcijaństwo dało sztuce całkowitą swobodę, czego ani przed nim, ani po nim nie zdołała uczynić żadna inna ludzka religia.

Żywiąc sztukę własnym ciałem, czyniąc jej niewzruszoną zasadą metafizyczną arcyrealny fakt odkupienia, chrześcijaństwo niczego nie żądało w zamian. Dlatego kulturze chrześcijańskiej nie grozi niebezpieczeństwo wewnętrznego zubożenia. Jest niewyczerpana, nieskończona, gdy, triumfując nad czasem, raz po raz zbiera wspaniałe chmury łaski i skrapia świat jej życiodajnym deszczem (Mandelsztam 2011: 61).

W zderzeniu z losem Mandelsztama, który został aresztowany jako autor wiersza krytykującego Stalina *** [Gdybym po węgiel sięgnął dla najwyższej chwały...] i oczekiwał skazującego wyroku, znacząco brzmią słowa o „żywieniu sztuki własnym ciałem” i „arcyrealnym fakcie odkupienia”.

Nakreślony przeze mnie kontekst biografii rosyjskiego poety-męczennika, a także jego rozważania na temat śmierci i odkupienia oraz sztuki chrześcijańskiej będą oświetlać interpretację jednego z wierszy Mandelsztama z czasu woroneskiego zesłania:

Как светотени мученик - Рембрандт, Я глубоко ушел в немеющее время, 
И резкость моего горящего ребра

Не охраняется ни сторожами теми,

Ни этим воином, что под грозою спят.

Простишь ли ты меня, великолепный брат

И мастер и отец чернозеленой теми?

Но око соколиного пера

И жаркие ларцы у полночи в гареме

Смущают не к добру, смущают без добра

Мехами сумрака взволнованное племя

(Mandelsztam 1983: 508).

Nieposiadający tytułu utwór Mandelsztama, napisany w lutym 1937 roku, w tłumaczeniu Stanisława Barańczaka brzmi tak:

Tak jak męczennik światłocienia - Rembrandt,

Musiałem ujść głęboko w czas, co z wolna niemiał,

Ale gorejącego ostrza mego żebra

Nie strzegą ani ci strażnicy, którzy drzemią,

Ani wojownik, co śpi wśród nawałnic.

Czy mi przebaczysz mój bracie wspaniały,

Któryś mistrzem i ojcem jest zieleni ciemnej,

Skoro sokolich piór źrenica srebrna

I żar szkatułek w porze północnej w haremie

Wiodą nie w stronę dobra, wiodą do zła jednak

Półmrocznymi futrami podburzone plemię ${ }^{2}$

(Mandelsztam 1983: 509).

2 Spójrzmy jeszcze na wersję zaproponowaną przez Adama Pomorskiego:

Niby męczennik światłocienia Rembrandt

$\mathrm{W}$ oniemiałego czasu zstąpiłem podziemie

I ostrości mojego płonącego żebra

Nie strzegą owi stróże ani ten, co drzemie,

Żołnierz, objęty cieniem sunącej nawały.

Ojcze zielonoczarnej ciemności, wspaniały

Bracie i mistrzu, daruj, że przemawiam szczerze:

Lecz oko sokolego pióra, złoto, srebra,

Gorąco szukał w północy haremie - 
Pojawienie się w pierwszym wersie nazwiska Rembrandta sugeruje, że źródeł inspiracji należałoby poszukiwać w twórczości siedemnastowiecznego mistrza holenderskiego. Szczegółowe informacje na ten temat odnajdujemy we fragmencie Wspomnień Nadieżdy Mandelsztam:

Ajschylos i Prometeusz z „Ody” w swobodnych wierszach doprowadzili do tematu tragedii. Temat męczeństwa powtórzył się w Rembrandcie, gdzie O.M. wprost mówi o sobie - „ostrość mojego płonącego żebra” i o swojej Golgocie pozbawionej wszelkiego majestatu. Rembrandtowska mała Golgota, tak jak czarno-czerwona grecka ceramika - reszta bogactw uniwersytetu w Dorpacie - znajdowała się wówczas w woroneskim muzeum, dokąd stale chodziliśmy (Mandelsztam 2015: 252).

Obraz, do którego Mandelsztam się odnosi, nie jest dziełem Rembrandta (mimo iż jemu początkowo był przypisywany), ale innego siedemnastowiecznego malarza holenderskiego, Jacoba de Weta Starszego. W latach trzydziestych xx wieku Mandelsztamowie byli jednak przekonani, że oglądają w woroneskim muzeum obraz Rembrandta. Brown stawia odważną tezę, że w wierszu „rembrandtowskim" chodzi nie tyle o intersemiotyczny przekład obrazu siedemnastowiecznego mistrza holenderskiego, ile o rozliczenie z własnym, poetyckim "portretem” Stalina, znanym jako tzw. Oda do Stalina, który miał pomóc Mandelsztamowi uniknąć zesłania i - w konsekwencji - śmierci:

Prawdziwym obrazem skrywającym się za tym wierszem nie jest przedstawienie męki Chrystusa z muzeum w Woroneżu, ale portret Stalina, który wyznaczył jako swoje zadanie Mandelsztam, zaś przebaczenie, którego szukał u „ojca zieleni [...] ciemnej” na płótnach Rembrandta, to przebaczenie za zaplanowany grzech, który popełnił z tak małym powodzeniem (Brown 1967: 586).

Oda na cześć Stalina byłaby w tym kontekście koniecznością, wierszem wymuszonym przez okoliczności, podyktowanym przez historię, ale i strach w tym sensie jest to ,grzech", rodzaj niechcianego paktu z diabłem, który jednak jawił się jako ostatni ratunek przed śmiercią. Dla Mandelsztama wspomnienie tego utworu musiało być bolesnym doświadczeniem, ponieważ stanowiło dowód uległości. Nieautentycznej odzie Mandelsztam zwykł zatem przeciwstawiać

Nie w dobrej sprawie nęcą ani w dobrej wierze

Zbałamucone mroku bukłakami plemię (Mandelsztam 2011: 403). 
wiersze, które wypływały z jego wnętrza, były zapisem intymnych poruszeń i pojawiały się w jego głowie w postaci gotowych muzycznych fraz.

Nawet jeśli przywołany przeze mnie Brown w ciekawy sposób dowodzi, że Mandelsztam mógł za pośrednictwem wiersza ${ }^{* * *}$ [Tak jak męczennik światłocienia - Rembrandt...] prosić Rembrandta o wybaczenie za poetyckie sportretowanie Stalina, to pominięcie ikonograficznego i biograficznego kontekstu (który wskazuje zresztą we Wspomnieniach Nadieżda Mandelsztam) wydaje mi się nieuzasadnioną interpretacyjną redukcją. W wierszu tym dostrzec można bowiem wyraźny ślad niezwykle silnego wrażenia, jakie wywarło na Mandelsztamie bezpośrednie obcowanie z dziełem holenderskiego mistrza. Jestem przekonana, że poeta głęboko przeżył - zarówno w planie estetycznym, jak i egzystencjalnym - spotkanie z tym obrazem. Za pomocą synekdochicznego utożsamienia porównuje swój ból do cierpienia Chrystusa, umierającego na krzyżu. W skazuje jednak równocześnie na odmienność historycznego tła jego i Chrystusowej Golgoty:

Ale gorejącego ostrza mego żebra

Nie strzegą ani ci strażnicy, którzy drzemią,

Ani wojownik, co śpi wśród nawałnic

(Mandelsztam 1983: 509).

Po aresztowaniu poety w zapiskach Nadieżdy Mandelsztam coraz częściej pojawiają się wzmianki o tym, że spotkanie ze śmiercią będzie nieuniknione. Co więcej, nieistnienie jawi się jej jako stan, który okaże się wybawieniem, przerwaniem niepokojącego, doprowadzającego do szaleństwa oczekiwania. Nadieżda Mandelsztam wielokrotnie wspomina o chorobie psychicznej męża, będącej konsekwencją przebywania w stalinowskim więzieniu. Achmatowa w refleksjach zatytułowanych Ze wspomnień o Mandelsztamie wyraża swoje głębokie ubolewanie: „W ostatnich latach z powodu jego choroby spotykaliśmy się bardzo rzadko, nie zdążyłam więc dokończyć rozmowy o czymś bardzo ważnym i przeczytać mu moich wierszy z lat trzydziestych (czyli Requiem)" (Achmatowa 2007: 615).

Przeświadczenie o tym, że śmierć postrzegana była w Rosji jako ratunek, łatwiejsza i pożądana droga ucieczki od więziennego świata, nieobce było także Achmatowej, wielkiej rosyjskiej poetce, wiernej przyjaciółce Mandelsztamów, która w swoim Requiem pomieściła apostrofę Do śmierci:

Skoro i tak masz nadejść, po cóż to odwlekać?

Otwarłam drzwi, zgasiłam światło. 
Bardzo mi teraz trudno - nie każ długo czekać

Na siebie, tak cudownie łatwą

(Achmatowa 2007: 88).

W innej części tego poematu, zatytułowanej Ukrzyżowanie, pojawia się fragment jakże bliski aluzjom Mandelsztamów do dziejów męki Chrystusa:

„Hosanna!” zaśpiewali aniołowie

I ogień rozpłomienił chmurę ciemną.

„O, czemuś mnie opuścił!” Ojcu powie,

A Matce: „Nie płacz ty nade mną...”

(Achmatowa 2007: 89).

Śmierć, wieńcząca biografię Mandelsztama, nosząca znamiona męczeństwa, jawi się jego żonie jako wyzwolenie: „Czekała go straszliwa droga i teraz wiemy, że jedynym wybawieniem była dlań śmierć” (Mandelsztam 2015: 178). Achmatowa wspomina, w jaki sposób Nadieżda Mandelsztam skomentowała informację o tym, że jej mąż umarł:

Po raz drugi aresztowano go 2 maja 1938 roku w sanatorium dla nerwowo chorych w pobliżu stacji Czerustje (w apogeum terroru jeżowszczyzny). W tym czasie mój syn od dwóch miesięcy siedział na Szpalernej (od 10 marca). O torturach wszyscy mówili już głośno. Nadia pojechała do Leningradu. Miała straszne oczy. Powiedziała: „Uspokoję się dopiero wtedy, kiedy dowiem się, że umarł”.

$\mathrm{Na}$ początku 1939 roku dostała krótki list od moskiewskiej przyjaciółki (Emma Giersztejn). „Naszej Lenie (Osmiorkinej) urodziła się dziewczynka, a nasza Nadiusza owdowiała" - pisała.

[Kiedy napisałam ostatnie słowo, z miasta przyjechała Ira i przywiozła list od Nadi. Kończy się tak: „a Osia, chwała Bogu, umarł”] (Achmatowa 2007: 639).

Ten kielich nie mógł go ominąć. Nadieżda Mandelsztam z ulgą przyjęła wiadomość o śmierci O.M.

\section{Wat o epizodzie w Getsemani}

W szkicu Ewangelia także jako arcydzieło literatury Aleksander Wat przedstawia odważną i odkrywczą interpretację epizodu w ogrodzie Getsemani. Wat stara 
się ukazać - przyjmując za punkt odniesienia ludzką perspektywę - istotną różnicę między Chrystusem a jego uczniami. Pisarz twierdzi, że trudniejsza niż samo doświadczenie męki była świadomość zbliżającej się śmierci, oczekiwanie na nią w samotności:

Nie wiem, czy zwrócono uwagę na uderzające niepodobieństwo ludzkiej natury Chrystusa do osobowości jego uczniów. [...] Ta przerażająca różnica Jezusa-człowieka tragicznie kulminuje w epizodzie, który odtąd w świadomości naszej prefiguruje całe odczucie nieprzezwyciężalnej samotności człowieka. Epizod w Gethsemane, gdzie Jezus przeżył całą mękę i cały strach tej męki w minutach i godzinach, które rozciągały się jak wieczność. I całą słabość ludzką, która w momencie nieskończonym szuka nie słowa nawet, nie gestu, nie pocieszenia, nie filozofii ani teodycei przyjaciół Hioba, ale spojrzenia współcierpienia, współodczuwania. On konał, a uczniowie najwierniejsi chrapali. Męka krzyża była już tylko powtórzeniem w planie nadnaturalnym i zarazem naturalnym; to, co było w ludzkiej rzeczywistości, w ludzkiej duszy, już się dokonało w ogrodzie Gethsemane. [...]

Consummatum est na krzyżu dokonało się już w duszy Jezusa w Gethsemane - a oni chrapali. Krzyż był znakiem widomym, i tylko w Eli, Eli, lamma sabachthani! znów wydarł się krzyk człowieka z Gethsemane, dysonans przejmujący grozą wieczną i wątpieniem wierzących. I dopiero krzyż, realność drewna i znak prawny tego śmiertelnego pręgierza obudził swoim widomym naturalizmem śpiących (Wat 2008: 714-715).

Tej nieprzystawalności postaw Chrystusa i jego uczniów Wat poszukuje także w sztuce. Interesują go zwłaszcza przedstawienia ostatniej wieczerzy i wieczerzy w Emaus. Ponieważ nie odnajduje obrazów, które potwierdziłyby jego tezę, odwołuje się do innego dzieła, będącego jedną z najbardziej enigmatycznych Rembrandtowskich „historii”" monumentalnego Sprzysiężenia Batawów pod wodza Claudiusa Civilisa (1661-1662) z Nationalmuseum

3 Warto wspomnieć, że literackie źródła Rembrandtowskich „historii” zbadała Amy Golahny w książce Rembrandt's Reading. The Artist's Bookshelf of Ancient Poetry and History (2003). Pisał o nich również Jan Białostocki: „Wyjaśnienie treści obrazowych, wyrażonych w skomplikowanym języku ikonograficznym, natrafia u Rembrandta na trudności związane ze szczególnym stosunkiem artysty do tradycji literackiej i ikonograficznej" (Białostocki 2009: 228). 
w Sztokholmie. To przedstawienie odsyła do - bardzo silnie zakorzenionego w świadomości Holendrów Xvir stulecia - mitu Batawii (Ziemba 2000: 99-106; Oczko 2009: 93-133). Obraz Sprzysiężenie Batawów budzi szczególne emocje nie tylko ze względu na to, co zostało na nim ukazane, ale także z powodu historii związanej z odrzuceniem go przez zamawiających"

Niderlandzka obojętność wobec monumentalnych obrazów historycznych nie zrodziła się wczoraj. Fakt, że Rembrandt jest ceniony przede wszystkim za ten rodzaj malarstwa, jest zwykle postrzegany jako wyjątek od reguły. Jego głównym monumentalnym zamówieniem jest Sprzysiężenie Claudiusa Civilisa, którego wykonanie dla amsterdamskiego ratusza zlecił mu burmistrz. Obraz nie zadowolił w pełni klientów, którzy domagali się wprowadzenia zmian. Pertraktacje dotyczące płatności nie powiodły się i Rembrandt musiał odciąć spore partie obrazu, by sprzedać go innym nabywcom. Po pewnym czasie dzieło odnalazło się w Sztokholmie, gdzie zajmuje dziś honorowe miejsce w Nationalmuseum. Historia Claudiusa Civilisa dowodzi skomplikowanych relacji Holendrów z malarstwem historycznym, a w tym przypadku - jeśli możemy wyrokować a posteriori - z jednym z najpiękniejszych monumentalnych przykładów tego rodzaju w malarstwie holenderskim XVII wieku (Kloek 2011: 217).

W liście z 31 grudnia 1961 roku Wat zwraca się do Leona Rappaporta z prośbą:

Czy mógłbyś mi dostarczyć - pisze - reprodukcję sztokholmskiego Rembrandta: półmityczny bohater powstania przeciw Rzymianom (Claudius? nie pamiętam) odbierający przysięgę spiskowców. Wisi pośrodku głównej ściany rembrandtowskiej w waszym muzeum. Z małą legendą, jeżeli to możliwe. Będę Ci bardzo wdzięczny - do czegoś mi to teraz potrzebne (Wat 2005: 466).

Wat zawarł w tym liście krótki opis płótna, będący świadectwem silnego wrażenia, jakie wywarło nam nim monumentalne dzieło Holendra, które oglądał w trakcie swojej wizyty w Sztokholmie. Jak podkreśla Kenneth Clark, obraz ten „przywołuje rodzaj quasi-mitycznej, heroiczno-magicznej przeszłości” (Clark 1966: 99). Z kolejnego listu Wata, pisanego 26 stycznia 1962 roku, dowiadujemy

4 Pisali o tym m.in. Michiel Franken (2004: 75-82) i Ernst van de Wetering (2011: 21-25). 
się, że Rappaport wysłał pisarzowi materiały dotyczące Rembrandtowskiego Sprzysiężenia Batawów:

Dziękuję serdecznie za reprodukcję, a szczególnie za bogate informacje najbardziej wyczerpujące i dokładne, jakie mógłbym mieć. Rembrandtdziści [sic!] na ogół ignorują ten obraz, w każdym razie niewiele o nim piszą (o ile mi wiadomo). Nawet tak wrażliwy i przenikliwy Simmel przemilcza go w swojej monografii. Mnie obraz ten, w swoim czasie, uderzył szyderstwem - właśnie nawiązanie do Ostatniej Wieczerzy jest tu dantejskie [słowo nieczytelne] persyflażowe. Potrzebne mi to obecnie jako skrót metaforyczny do opisu pewnych sytuacji polityczno-religijnych (Wat 2005: 467).

Sądzę, że pod sformułowaniem „bogate informacje najbardziej wyczerpujące i dokładne, jakie mógłbym mieć” może kryć się wydany w 1956 roku monograficzny numer „Konsthistorisk Tidskrift” poświęcony arcydziełu Rembrandta. Na ten trop naprowadza zaproponowane przez Wata porównanie holenderskiego płótna z Ostatnią Wieczerzą Leonarda, które pojawia się również w artykule Carla Nordenfalka Some Facts about Rembrandt's Claudius Civilis opublikowanym właśnie w „Konsthistorisk Tidskrift” (1956). Badacz podkreśla bowiem:

Grupując postaci przy stole, Rembrandt [...], jak często się wskazuje, za wzór potraktował Ostatniq Wieczerzę Leonarda. Jak wynika z zachowanych rysunków, kompozycja ta interesowała go również pod koniec lat trzydziestych xviI wieku. Tym, co zasadniczo odróżnia Rembrandtowską interpretację tego tematu od tej zaproponowanej przez jego rywali: Flincka i Ovensa, jest fakt, że wyobraził on sobie to wydarzenie nie jako radosną ucztę dla paradujących wojowników, ale raczej jako uroczystą, sakralną ceremonię, i ta odmienność jest głównym odniesieniem do Leonarda; Claudius Civilis gromadzi zwolenników wokół siebie jak Chrystus swoich uczniów. Zgodność pomiędzy Ostatnia Wieczerza z Santa Maria delle Grazie szczególnie uderza, kiedy spoglądamy na zdjęcie rentgenowskie obrazu, na którym z tyłu widzimy siedzącego Batawa, schowanego za stojącym młodzieńcem, i - jak u Leonarda mamy wówczas za stołem dwie rytmicznie zebrane trzyosobowe grupy 5 (Nordenfalk 1956: 79-80).

5 Pisali o tym również: Clark (1966: 61-62); Nordenfalk (1982: 32) i van de Wetering (2011: 23). 
Myślę, że tekstem, w którym Wat chciał wykorzystać Rembrandtowskie arcydzieło jako „skrót metaforyczny do opisu pewnych sytuacji polityczno-religijnych”, jest szkic Ewangelia także jako arcydzieło literatury, napisany najprawdopodobniej w latach 1963-1965. Pisarz nie odnajduje malarskich prób ukazania nieskończonej samotności Syna Bożego, świadomego zbliżającej się śmierci, dlatego wybiera Rembrandtowskie Sprzysiężenie Batawów pod wodzą Claudiusa Civilisa, oparte na kompozycyjnym schemacie Ostatniej Wieczerzy Leonarda da Vinci, i akcentuje zasadniczą różnicę związaną z ideologiczną wymową tych dzieł:

Rzecz dziwna - nikt z malarzy, których znam, nawet malarz-myśliciel da Vinci, nawet najgłębszy Rembrandt, nie dostrzegł tej różnicy, która stanowi o samotności Jezusa-człowieka. Bellini w Wieczerzy $w$ Emaus skupia na Chrystusie wszystkie światła i wszystkie wektory perspektywiczne. Może przeczuwał to Giotto? U Leonarda to tylko twarz człowieka, którego losem jest przyjąć wszystkie cierpienia. Ale jest jeden obraz Rembrandta, który zastanawia i niepokoi. Wisi teraz w Sztokholmie. Syndycy w Amsterdamie, którzy go zamówili, odmówili przyjęcia - miał uświetniać batawskiego bohatera narodowego w momencie zaprzysiężenia spiskowców, batawskiego wodza, który wszczął bunt przeciwko Rzymianom.

Co jest w nim uderzające i niepokojące to podobieństwo wzorów ikonograficznych Ostatniej Wieczerzy. W spiskowcach Rembrandt prezentuje fizjonomikę i nawet sposób usytuowania apostołów. Jest między nimi nawet ktoś, kto nadaje się do roli Judasza; zebrani usadowieni naokoło stołu, ale On jest o głowę wyższy, ogromny Goliat, jest szkaradny, jak gdyby ślepy na jedno oko, w ogromnej tiarze wysadzanej klejnotami, która nadaje temu kalibanowi wygląd króla Azteków. Więc umieszczenie tego potwora w scenerii ostatniej wieczerzy jest szyderstwem, bluźnierczym szyderstwem. Ale ten potwór jest z innego kruszca niż jego spiskowcy. Jest od nich wyższy o głowę, jest z innego świata i jest beznadziejnie samotny, a w zaprzysięganiu ich skrzyżowaniem mieczy jest już zdrada. Samotność i zdrada (Wat 2008: 715).

Antoni Ziemba zwraca uwagę na fakt, że w twórczości Rembrandta wyróżnia się dwie metody wchodzenia $\mathrm{w}$ dialog $\mathrm{z}$ dziełami dawnych mistrzów: emulację, czyli naśladownictwo klasycznych wzorów, oraz „strategię zupełnego odróżnienia” (Ziemba 2008: 39). W przypadku zmagań Rembrandta z Ostatnia Wieczerza dostrzegalny jest zarówno pierwszy, jak i drugi sposób nawiązań. O naśladownictwie mówić należy bowiem w odniesieniu do rysunków artysty 
z lat trzydziestych XVII wieku, przedstawiających Ostatniq Wieczerzę (szczegółowo omawia to Clark (1966: 53-57)), zaś ze znaczącym przeformułowaniem czy wręcz negacją malarskiej tradycji mamy do czynienia w Rembrandtowskim Weselu Samsona z 1638 roku z Gemäldegalerie Alte Meister w Dreźnie, gdzie Chrystus z obrazu Leonarda zastąpiony został przez postawną pannę młodą (co może być odczytywane jako rodzaj świętokradztwa (Clark 1966: 57)), w malowanych w 1662 roku Syndykach z kolekcji amsterdamskiego Rijskmusuem, jak również w interesującym nas Sprzysiężeniu Batawów pod wodzą Claudiusa Civilisa (Clark 1966: 61-62).

W interpretacji Wata porównanie z Leonardem, nawet jeśli pisarz sugeruje pewne czytelne kompozycyjne nawiązania, służy całkowitemu odróżnieniu, co - jak pisze Ziemba - charakterystyczne jest raczej dla późnej twórczości Rembrandta (Ziemba 2008: 39). Przede wszystkim jednak dostrzegamy, że sam obraz staje się dla autora Mojego wieku jedynie pretekstem do snucia rozważań bardzo silnie osadzonych w kontekście religijnym. Wat stara się domknąć swoje refleksje na temat wyjątkowości Chrystusowego człowieczeństwa, wskazując na przeciwieństwo dwóch postaci - Jezusa i św. Pawła:

Ta podejrzana kwiecistość św. Pawła - pisze - ta retoryka uczuć i słów, naśladownictwo co mniejszych retorów azjatyckiego Rzymu i wzór dla najniesmaczniejszych próbek literackich, te jego hymny do miłości - trudno o większy kontrast z surową miłością i skromną miłością, o której mówił Jezus (Wat 2008: 716)

Wat usiłuje w ten sposób odnaleźć korzenie własnego żydostwa, z którego jest dumny, ale które na początku odrzucił, by później bardzo długo do niego dochodzić7. Tym źródłem okazuje się postać Chrystusa, będąca uosobieniem żydowskiego losu. W szkicu O religii: Łubianka 1941 - Italia 1957 pisarz tłumaczy:

6 Podobną opinię na temat św. Pawła miał Henryk Elzenberg: „Apostołowie miłości. Jeżeli ci Paweł powtarza: «kochaj ludzi», to jakże często znaczy to «kochaj Pawła, bądź Pawłu bratem». Wielkie będzie jego zdziwienie jeśli ci strzeli do głowy zastosowanie się do tego wskazania także w stosunku do Piotra, z którym Paweł ma spór o trzy grosze" (Elzenberg 1994: 115, wyróż. H.E.).

7 „Nie mam w sobie na ogół grzechu dumy, jest mi chyba obcy (co naprawdę można wiedzieć o sobie, istocie najbardziej nieznajomej, prócz zdań hipotetycznych, z nieodmiennym i imperatywnym znakiem zapytania?). Ale na starość znalazłem w sobie to niemądre uczucie i łapię się na tym, że jestem dumny ze swego żydostwa i nic, co było kiedykolwiek żydowskie, nie jest mi obce i im dalsze jest w czasie, tym mówi we mnie głośniej: jestem, czuwam, abyś pozostał mi wierny. Żadna religia dawniejsza nie mówi, 
Czując się zatem tak unisono jak kamerton z nastrojem religijnym moich zamarstynowskich współwięźniów, nie widziałem żadnego dla siebie pomostu do Kościoła. Ale, odwrotnie, sam Jezus, żydowski syn Maryi, był dla mnie wtedy - i zawsze - Żydem od alfy i omegi, najwyższym wcieleniem nie tylko psychologii żydowskiej, ale i losu żydowskiego. Jak portrety Rembrandta według trafnej uwagi Georga Simmla ujawniają jednocześnie i psychologię, i biografię portretowanego, tak w obrazie Chrystusa była jedność osobiście męczeńskiej historii Żydów. Jak często spotykałem właśnie śród pobożnych dusze naturaliter chrześcijańskie! I odwrotnie, rzadko widziałem dusze tak antychrystusowe, jak osławiony padre Pio (Wat 1998: 347-348).

Jakże bliski Mandelsztamowi (zarówno w planie estetycznym, jak i egzystencjalnym) jest tutaj Wat, piszący o symbiotycznym współistnieniu biografii i psychologii portretowanej postaci oraz o „męczeńskiej historii Żydów”, której prefiguracją była Chrystusowa Golgota. Oto okazuje się, że w postaci Chrystusa zbiegają się głęboko przeżyta historia osobista i dzieje wspólnoty. Wat dostrzega w Bożym Synu człowieka, „syna Maryi”, który - posłuszny Ojcu - jest gotów złożyć ofiarę z własnego życia. Dzieje Chrystusowej męki nie są jednak wyłącznie historią człowieka, jest w nich ukryte przesłanie o mesjańskim charakterze narodu żydowskiego, wydanego - podobnie jak Chrystus - na pastwę ludzi okrutnych i bezwzględnych. Co istotne, według Wata tylko podobieństwo do pokornej postawy Chrystusa jest rękojmią prawdziwie religijnego stosunku do rzeczywistości, który nie kryje się w zewnętrznym sztafażu, niewiele ma wspólnego z rytuałem, a zasadza się przede wszystkim na podejmowanych ciągle na nowo próbach naśladowania Chrystusa.

W przytoczonym fragmencie Wat nawiązuje także do własnego spotkania z ojcem Pio. W Zjawach Saraceńskich w następujący sposób zrelacjonował je Gustaw Herling-Grudziński:

Była to surowość nieokrzesanego proboszcza wiejskiego. Podam ci przykład, z którym zresztą zetknąłem się osobiście. Mój przyjaciel, znany poeta polski, cierpiał od lat na straszliwe bóle głowy, które nieraz doprowadzały go do krzyków. Lekarze byli absolutnie bezradni, rozkładali ręce, co najwyżej zapisywali mu narkotyczne środki uśmierzające,

a nawet późniejsze nie czyniły z nakazu wierności naczelnego imperatywu. Odszedłem od niej do Chrystusa, aby przez Jezusa do niej wrócić. Wszystko, wszystkie odstępstwa, zdrady, ekstremizmy w końcu się tłumaczą" (Wat 2008: 716-717). 
na dłuższą metę zatruwające organizm. Podróż do Włoch zawiodła mojego przyjaciela z żoną do Neapolu. Byłem w hotelu świadkiem jednego z jego ataków. Dosłownie wył z bólu. Mój przyjaciel był katolikiem neofitą, urodził się w innej wierze. I był katolikiem bardzo intelektualnym, nie przywiązywał nadmiernej wagi do praktyk religijnych. Ktoś w Paryżu (a przyjechał do Neapolu z Paryża) doradził mu wyprawę z Neapolu do San Giovanni Rotondo w stosunkowo bliskiej Apulii. Wybrali się oboje, on i żona, wczesnym ranem, mieli wrócić przed północą. Umówiliśmy się w jego hotelu po północy. Wyglądał jak człowiek zbity i skopany. Co się stało? Gdy przyszła kolej na niego, wiejski proboszcz zapytał go machinalnie: „Kiedy ostatni raz byłeś u spowiedzi?” Odpowiedział, zgodnie z prawdą, że bardzo dawno; tak dawno, że nie pamięta. Padre Pio wyprostował się, wyciągnął groźnym gestem rozkazującym prawą rękę i krzyknął gniewnie: „Precz od ołtarza” (Herling-Grudziński 2002: 210).

Ojciec Pio staje się dwudziestowiecznym uosobieniem surowej miłości św. Pawła, a więc przeciwieństwem miłości Chrystusowej. O tym spotkaniu opowiada również sam Wat w szkicu O religii: Łubianka 1941 - Italia 1957, wskazując na fundamentalną różnicę postaw ojca Pio i Chrystusa: „Zrozpaczona Ola - podsumowuje Wat - sprowadziła padre Agostino. «Jest nie tylko padre Pio - powiedział i zajrzał mi głęboko w oczy - jest ktoś wyższy od padre Pio: Jezus Chrystus»" (Wat 1998: 350). W swoim eseju pisarz nie tylko odnosi się do własnego losu, ale także stawia bardziej uniwersalne pytanie dotyczące współczesnego modelu chrześcijaństwa, które wszak nierozerwalnie związane jest $\mathrm{z}$ historią Żydów.

W cytowanym wcześniej fragmencie O religii: Łubianka 1941 - Italia 1957 pojawia się również wątek związany z Simmlowską interpretacją twórczości Rembrandta, a dokładniej z dostrzeżoną przez niemieckiego filozofa zdolnością Holendra do malarskiego oddania zarówno biografii, jak i psychologicznego wymiaru portretowanej postaci. Wat odwołuje się tu - jak sądzę - do jednego z rozdziałów pracy Georga Simmla Rembrandt. Szkic z filozofii sztuki, zatytułowanego Bycie i stawanie się w portrecie:

Oglądając portrety Rembrandta, czujemy wyraźnie, że teraźniejszy wizerunek wyłonił się z całego życiorysu, wydarzenie za wydarzeniem; obraz czasu obecnego pozwala nam wspiąć się na szczyt, z którego widać całą do niego wiodącą drogę, przy czym nie uświadczymy tu żadnych treści przeszłych podanych w sposób naturalistyczny, jak to 
widać na portretach o manierze psychoanalitycznej. To byłoby anegdotą, literaturą, a więc czymś spoza czystej linii sztuki. W cudowny sposób udaje się Rembrandtowi wtłoczyć w wyjątkowość wizerunku całe życie, które do niego doprowadziło, tę, jakby to określić, formalną rytmikę, zgodność, stopniowanie wydarzeń witalnego procesu (Simmel 2005: 107).

Simmel podkreśla, że Rembrandt:

tworzy specyficzny rodzaj „ogólności”, przedstawienie idealnego indywiduum mianowicie, jakie powstaje na drodze abstrakcji i składa się ze wszystkich pojedynczych momentów życia. U Rembrandta ogólność indywidualnego człowieka oznacza akumulację tych właśnie momentów, w pewnym stopniu zachowujących historyczny porządek (Simmel 2005: 108).

W taki sposób, w jaki Rembrandt ukazuje portretowane osoby, Wat odczytuje postać Chrystusa, którego postrzega jako „najwyższe wcielenie nie tylko psychologii żydowskiej, ale i losu żydowskiego". Podobnie jak w przypadku interpretacji Sprzysiężenia Batawów pod wodza Claudiusa Civilisa, malarskie nawiązanie ma charakter pretekstowy. Wat w pewnym stopniu dotyka istoty Rembrandtowskiego geniuszu, jednak najważniejsze okazują się dla niego własne rozważania, gdzie konkretne obrazy są zarówno punktem wyjścia, jak i erudycyjną ilustracją formułowanych tez. W tym przede wszystkim przejawia się specyfika proponowanych przez Wata odczytań dzieł sztuki - estetyka konkretnego malarza istotna jest o tyle, o ile oświetla estetykę pisarza zainteresowanego jego twórczością.

Na podobnych prawach aluzja do Rembrandta pojawia się w wierszu Mandelsztama. Rosyjski poeta wyraźnie sugeruje czytelnikowi, że wiersz będzie opierał się na konkretnym intertekstualnym nawiązaniu, którego odszyfrowanie istotne jest dla zrozumienia całości, ale nie skupia się wyłącznie na opisie dzieła sztuki. Kreśli malarskie tło, ponieważ okazuje się ono konieczne dla sformułowania trudnego autobiograficznego wyznania. Oglądana w woroneskim muzeum „mała Golgota” staje się prefiguracją Mandelsztamowej Golgoty.

Odwołując się do tez zawartych w szkicu Skriabin i chrześcijaństwo, można zatem stwierdzić, że twórczość Mandelsztama i Wata, tak silnie powiązana z tragicznym losem tych poetów, znalazła swoją kulminację w ich śmierci. Szczególnym wyrazem tego przeświadczenia pozostają zaś wiersz ${ }^{* * *}[$ Tak jak męczennik światłocienia - Rembrandt...] oraz szkic Ewangelia także jako 
arcydzieło literatury, w których obydwaj autorzy odnoszą się do twórczości Rembrandta (przypomnę, że Mandelsztam nie wiedział, iż oglądany w woroneskim muzeum obraz jest autorstwa Jacoba de Weta Starszego). Celem tego odwołania nie jest jednak estetyczna przyjemność, choć i Mandelsztam, i Wat wysoko cenili malarstwo Holendra. Stawka tego intersemiotycznego dialogu jest dużo większa - oto bowiem pisarze odnajdują figurę samotnego Chrystusa, targanego niepokojem, nawet - ulegającego obawom, a mimo to konsekwentnie wypełniającego swą misję. Taki Chrystus, zarazem ludzki (bo przestraszony i osamotniony), ale i boski (bo nieugięty), staje się dla Mandelsztama i Wata życiowym wzorem, jego postawa stanowi uzasadnienie ich egzystencjalnych lęków. Za pośrednictwem malarskich aluzji obaj pisarze mówią zatem tak naprawdę o sobie i dramatycznej historii xx wieku. W tym też sensie wzbogacić można spostrzeżenia przywołanej już przeze mnie Chalard-Fillaudeau - otóż badaczka wyraźnie zaznaczyła, że dla dwudziestowiecznych pisarzy Rembrandt stał się lustrem, w którym dostrzegali samych siebie (zob. Chalard-Fillaudeau 2004: 271). To prawda, przykłady utworów Mandelsztama oraz Wata pokazują jednak, że dzieło Rembrandta nie tylko może posłużyć do wyrażania osobistych lęków, ale też pozwala uporządkować relacje między jednostką a historią - staje się zatem wyzwaniem nie tylko estetycznym, ale i egzystencjalnym.

\section{| Bibliografia}

Achmatowa Anna (2007), Droga wszystkiej ziemi. Poezja. Proza. Dramat, wybrał, przełożył i komentarzami opatrzył Adam Pomorski, open, Warszawa.

Białostocki Jan (2009), Badania ikonograficzne nad Rembrandtem, w: tenże, O dawnej sztuce, jej teorii i historii, red. Maria Poprzęcka, Antoni Ziemba, Sergiusz Michalski, słowo/obraz terytoria, Gdańsk, s. 223-250.

Brown Clarence (1967), Into the Heart of Darkness: Mandelstam's Ode to Stalin, „Slavic Review”, t. 26, nr 4, s. 584-604.

Chalard-Fillaudeau Anne (2004), Rembrandt, l'artiste au fil des textes. Rembrandt dans la littérature et la philosophie européenne depuis 1699, L'Harmattan, Paris.

Clark Kenneth (1966), Rembrandt and the Italian Renaissance, Norton, London.

Elzenberg Henryk (1994), Kłopot $z$ istnieniem. Aforyzmy w porzadku czasu, Znak, Kraków.

Franken Michiel (2004), Changing Direction: The Reconstruction of the Genesis of Rembrandt „Conspiracy of the Batavians under Claudius Civilis” Reconsidered, „Art Bulletin of Nationalmuseum Stockholm”, t. 11, s. 75-82. 
Golahny Amy (2003), Rembrandt's Reading. The Artist's Bookshelf of Ancient Poetry and History, Amsterdam University Press, Amsterdam.

Herling-Grudziński Gustaw (2002), Zjawy Saraceńskie, w: tenże, Biała noc miłości. Opowiadania, Czytelnik, Warszawa, s. 181-222.

Kloek Walter (2011), L'Importance des tablaux narratifs en Hollande au Xvile siècle, w: Ilone et George Kremer. Héritiers de l'Âge d'Or hollandais, red. Walter Kloek, Pinacothèque de Paris, Paris.

Mandelsztam Nadieżda (2015), Wspomnienia, przeł. Jerzy Czech, wstęp Josif Brodski, Agora, Warszawa.

Mandelsztam Osip (1983), Poezje, wybór, redakcja i posłowie Maria Leśniewska, Wydawnictwo Literackie, Kraków-Wrocław.

Mandelsztam Osip (2011), Nieograbiony i nierozgromiony. Wiersze i szkice, wybrał, przełożył i komentarzami opatrzył Adam Pomorski, Wydawnictwo Naukowe i Literackie OpEN, Warszawa.

McQueen Alison (2003), The Rise of the Cult of Rembrandt. Reinventing an Old Master in Nineteenth-Century France, AuP, Amsterdam.

Nordenfalk Carl (1956), Some Facts about Rembrandt's Claudius Civilis, „Konsthistorisk Tidskrift", t. 25, nr 1-4, s. 71-93.

Nordenfalk Carl (1982), The Batavians' Oath of Allegiance. Rembrandt's Only Monumental Painting, Nationalmuseum, Stockholm.

Oczko Piotr (2009), Wokół batawizmu i sarmatyzmu, w: tenże, W najdroższej Holandyjej... Szkice o siedemnastowiecznym dramacie i kulturze niderlandzkiej, Księgarnia Akademicka, Kraków, s. 93-133.

Pismo Święte Starego i Nowego Testamentu (1990) w przekładzie z jęz. oryginalnych, oprac. zespół biblistów polskich z inicjatywy benedyktynów tynieckich, wyd. 3 popr., Wydawnictwo Pallotinum, Poznań-Warszawa.

Rosales Rodríguez Agnieszka (2008), Śladami dawnych mistrzów. Mit Holandii złotego wieku $w$ dziewiętnastowiecznej kulturze artystycznej, Wydawnictwo Uniwersytetu Warszawskiego, Warszawa.

Silver Larry, Perlove Shelley (2011), Rembrandt's Jesus, w: Rembrandt and the Face of Jesus, red. Lloyd Dewitt, przedm. Seymour Slive, Philadelphia Museum of Art, Musée du Louvre, Detroit Institute of Art, Philadelphia, Paris, Detroit, s. 75-107.

Simmel Georg (2005), Rembrandt. Szkic z filozofii sztuki, przeł. Wojciech Zahaczewski, przekład przejrzała Kamila Najdek, „Sztuka i Filozofia”, t. 27, s. $98-128$.

Stankowska Agata (2013), „żeby nie widzieć oczu zapatrzonych w nic”. O twórczości Czesława Miłosza, Wydawnictwo Naukowe UAm, Poznań.

Śniedziewska Magdalena (2014), Siedemnastowieczne malarstwo holenderskie w literaturze polskiej po 1918 roku, Wydawnictwo Naukowe umк, Toruń. 
Wat Aleksander (2008), Ewangelia także jako arcydzieło literatury, w: tenże, Publicystyka, zebrał, oprac., przypisami, posłowiem oraz indeksami opatrzył Piotr Pietrych, Czytelnik, Warszawa, s. 714-719.

Wat Aleksander (2005), Korespondencja, cz. 1, wybrała, opracowała i przypisami opatrzyła Alina Kowalczykowa, Czytelnik, Warszawa.

Wat Aleksander (1998), O religii: Łubianka 1941 - Italia 1957, w: tenże, Mój wiek. Pamiętnik mówiony, cz. 2, rozm. prowadził i przedm. opatrzył Czesław Miłosz, do druku przygotowała Lidia Ciołkoszowa, Czytelnik, Warszawa, s. 341-351.

van de Wetering Ernst (2011), Rembrandt's Painting „The Conspiracy of the Batavian under Claudius Civilis", przeł. Murray Pearson, w: Opstand als Opdracht. The Batavian Comissions. Flinck, Ovens, Lievens, Jordaens, De Groot, Bol, Rembrandt, red. Marianna van der Zwaag, Renske Cohen Tervaert, przeł. Yvette Rosenberg, Murray Pearson, Amsterdam Royal Palace Foundation, Amsterdam, s. 21-26.

Ziemba Antoni (200o), Republika Batawów, w: tenże, Nowe dzieci Izraela. Stary Testament w kulturze holenderskiej XVII wieku, Neriton, Warszawa, s. 99-106. Ziemba Antoni (2008), Nowa wizja osobowości i twórczości Rembrandta: dwie wystawy Roku Rembrandtowskiego (i jeden obraz polski), „Rocznik Historii Sztuki”, t. 33, s. 29-44.

\section{| Abstrakt}

Magdalena ŚNIEdZiewsKa

Rembrandt i samotność Chrystusa: ${ }^{* * *}$ [Tak jak męczennik światłocienia Rembrandt...] Osipa Mandelsztama i Ewangelia także jako arcydzieło literatury Aleksandra Wata

W artykule staram się opisać pomijane dotychczas przez badaczy relacje między tekstami a postaciami pojawiającymi się na płótnach Rembrandta. Interesuje mnie związek pomiędzy wierszem Mandelsztama ${ }^{\star * *}$ [Tak jak męczennik światłocienia - Rembrandt...], szkicem Wata Ewangelia także jako arcydzieło literatury a Rembrandtowskim wyobrażeniem Chrystusa oraz - co istotne w przypadku Wata - batawskiego wodza, Claudiusa Civilisa. Przykłady utworów Mandelsztama oraz Wata pokazują, że dzieło Rembrandta nie tylko może posłużyć do wyrażania osobistych lęków, ale pozwala też uporządkować relacje między jednostką a historią staje się zatem wyzwaniem nie tylko estetycznym, ale i egzystencjalnym. Dowodzę także, iż twórczość Mandelsztama i Wata, tak silnie powiązana z tragicznym losem tych poetów, znalazła swoją kulminację w ich śmierci. 
Słowa kluczowe: Osip Mandesztam; Nadieżda Mandelsztam; Aleksander Wat; Rembrandt; Golgota; epizod w ogrodzie Getsemani; literatura i malarstwo

\section{| Abstract}

\section{Magdalena ŚniedziewsKa}

Rembrandt and the Loneliness of Christ: Osip Mandelstam's

*** [Like Rembrandt, Martyr of Chiaroscuro...] and Aleksander Wat's The Gospel also as a Literary Masterpiece

In this article, I try to describe the relationships (that have been overlooked by researchers) between texts and characters appearing on Rembrandt's canvases. I am interested in the relationship between the poem by Mandelstam ${ }^{* * *}$ [Like Rembrandt, martyr of chiaroscuro...], the essay of Wat Gospel also as a masterpiece of literature and Rembrandt's image of Christ and - importantly in the case of Wat the Batavian chieftain, Claudius Civilis. Examples of works by Mandelstam and Wat show that Rembrandt's painting can be used not only to express personal fears, but also allows to organize the relationship between the human entity and history: thus it becomes not only an aesthetic but also an existential challenge. I also prove that the work of Mandelstam and Wat, so strongly connected with the tragic fate of these poets, found its culmination in their deaths.

Keywords: Osip Mandelsztam; Nadezdha Mandelsztam; Aleksander Wat;

Rembrandt; Golgothe; episode in the Gethsemane; literature and painting

\section{| Nota o autorze}

Magdalena Śniedziewska - dr, polonistka i italianistka, adiunkt w Zakładzie Teorii Literatury w Instytucie Filologii Polskiej Uniwersytetu Wrocławskiego. W latach 2015-2018 adiunkt w Pracowni Poetyki Historycznej IBL PAN w ramach programu FUGA (NCN). Autorka książek: Wierność rzeczywistości. Zbigniew Herbert o postawie wobec świata i problemach jego reprezentacji (Kraków 2013), Siedemnastowieczne malarstwo holenderskie w literaturze polskiej po 1918 roku (Toruń 2014), „Osobiste sprawy i tematy”. Gustaw Herling-Grudzinski wobec dwudziestowiecznej literatury 
włoskiej (Warszawa 2019), „Nuta autobiograficzna”. O twórczości Gustawa Herlinga-Grudzińskiego (Kraków-Warszawa 2019). Zajmuje się związkami literatury i malarstwa, recepcją literatury włoskiej w Polsce oraz motywami ptasimi w literaturze. E-mail: magdalena.sniedziewska@uwr.edu.pl ORCID: 0000-0002-7390-5340 